\title{
A OUTRA FACE DO GEÓGRAFO
}

Virgílio Meira SoARes ${ }^{1}$

Perguntaram-me os promotores da homenagem ao Professor Carlos Alberto Medeiros se estaria disposto a colaborar, por escrito, nessa iniciativa. Sem sequer reflectir, aceitei de imediato.

Apesar de saber que não me pediam para falar de Geografia, mal imaginava a dificuldade que iria ter, não por lhe faltarem atributos que justifiquem a homenagem, mas por me faltarem palavras que, de algum modo, façam a justiça que lhe é devida.

Tive o privilégio de conhecer o Carlos Alberto há poucos anos. Apesar de ser colega da Universidade, nunca tinha privado com ele até ao momento em que, por sugestão de um amigo comum, que lhe fez largos elogios, entendi considerar a hipótese de o convidar para Vice-reitor da Universidade de Lisboa.

Falámos na altura e, desde logo, dei conta que estava perante alguém que, com um valor inquestionável, demonstrava uma humildade genuína. Resolvi apostar e convidei-o.

Foram quatro anos de convívio e de aprendizagem para mim que, ao fim de vários anos como reitor, pensava que já pouco teria que aprender nestas lides!

$\mathrm{Na}$ distribuição de tarefas que fizemos na equipa reitoral, coube-lhe, entre várias outras coisas, coordenar a parte pedagógica e científica, áreas sensíveis numa instituição em rápida mudança. E, nesses campos como nos outros, foi eficiente e competente, discreto, bom negociador, tendo revelado uma capacidade de diálogo fora do comum, recebendo a admiração dos muitos que com ele trabalharam e privaram.

O seu ar pacífico poderia, contudo, enganar os que pensavam ser possível levá-lo a ceder a propostas menos correctas. Nada mais errado. O Carlos Alberto não era facilmente enganado e, se pressentia que o contactavam com essa intenção, também se zangava e tinha a qualidade de saber dizer 'não'. Fazia-o com a boa educação que lhe é característica, mas mantinha a firmeza das suas convicções.

1 Professor Catedrático da Faculdade de Ciências da Universidade de Lisboa. Reitor da Universidade de Lisboa de 1986 a 1998. 
Em determinados casos tinha, como todos nós, dúvidas sobre o modo de actuar. Nunca lhe foi difícil discutir com a restante equipa essas dúvidas, aceitar as sugestões e decidir em conformidade. Embora a última palavra fosse sempre do reitor, nunca senti que, da sua parte, houvesse a intenção de fugir às responsabilidades nesses momentos. A sua honestidade intelectual impunha-lhe a consulta a quem, como ele, tinha muitas vezes que decidir casos difíceis.

Como atrás referi, o Carlos Alberto ficou com a responsabilidade de coordenar as questões científicas e pedagógicas. Era uma altura complicada em que as reitorias começaram a ter uma maior intervenção nas matérias (os Centros de Investigação haviam sido, recentemente, integrados nas Universidades) e a criação e a modificação de cursos já não podia ser uma simples formalidade em que o Senado se limitava a 'pôr o selo branco' sobre as propostas que eram apresentadas. As dificuldades orçamentais implicavam uma certa contenção. Não hesitei em delegar nele a Presidência da Comissão Científica do Senado. Exerceu-a em plenitude, sem sobressaltos, tendo merecido a admiração dos colegas que dela faziam parte, sem excepção conhecida.

Uma das qualidades que, normalmente, aprecio em quem trabalha comigo é a lealdade, que não se confunde, no entanto, com uma cega fidelidade. A lealdade vai para além da correcção de procedimentos, da concordância permanente com o 'chefe', da rectidão das decisões que se tomam. A capacidade de discordar, a frontalidade nas relações pessoais, a amizade, a disponibilidade para suprir as faltas e insuficiências dos membros da equipa com quem se trabalha, a entrega a causas, o respeito por quem se 'chefia', a 'dedicação exclusiva' ao trabalho e, até mesmo, o não se reivindicar um sucesso em proveito próprio são componentes essenciais da verdadeira lealdade que não se encontram frequentemente. São precisamente estas características que tornam o Carlos Alberto uma pessoa especial. Não me lembro de lhe ter faltado, ainda que momentaneamente, qualquer destas características.

Foram anos que recordo com gosto, pela saudável relação que estabelecemos e que, apesar das vidas afastadas que levamos, ainda hoje se mantém. Mais recentemente, estava eu com dificuldades em encontrar alguém que me desse um apoio pontual, recorri ao Carlos Alberto, pedindo-lhe que me ajudasse. Tratava-se de algo relacionado com a avaliação de um curso. 'Estou reformado e afastado das lides. Temo não estar à altura para fazer o que me pede', disse por estas, ou semelhantes, palavras. Mais uma vez confirmei e admirei a humildade e a seriedade intelectual. Claro que foi convencido e fez um bom trabalho, como seria de esperar.

Como disse de início, faltam-me palavras para ser mais claro. Quem tem o respeito e admiração dos colegas e dos funcionários, pelas razões apontadas, como é o caso do Carlos Alberto, merece que aqueles que sentem ser dever enaltecer as suas qualidades, e não são poucos, se juntem e se manifestem.

Parabéns pela iniciativa.

Carlos Alberto, para si, um grande abraço de agradecimento, de amizade e de admiração do seu amigo 